\title{
Effects of Strategic Issue Diagnosis Process (SIDP) on Profitability of Private Universities in Kenya: Case of the Catholic University of Eastern Africa (CUEA) ${ }^{1}$
}

\author{
Aloys Ayako $^{1} \&$ Annette Ayako ${ }^{1}$ \\ ${ }^{1}$ Faculty of Commerce, The Catholic University of Eastern Africa, P.O. Box 62157-00200, Nairobi, Kenya. \\ Correspondence: Aloys Ayako, Faculty of Commerce, The Catholic University of Eastern Africa, P.O. Box 62157- \\ 00200, Nairobi, Kenya.
}

Received: July 15, 2015

Accepted: July 29, 2015

Available online: August 28, 2015

doi:10.11114/afa.v2i1.1057

URL: http://dx.doi.org/10.11114/afa.v2i1.1057

\begin{abstract}
The study analyzed the effects of strategic issue diagnosis process (SIDP) on the profitability of the Catholic University of Eastern Africa (CUEA). The study used a census survey design of the fifty members of the top management team (TMT) of the University. The survey data was analyzed using factor analysis and regression analysis. Factor analysis using principal components and varimax (orthogonal) rotation (to maximize variable loadings to each factor) was conducted to reduce the dimensionality and identify the factors (latent variables) and labels (constructs) of both the SIDP and profitability of CUEA. The regression analysis results showed that the joint effect of the six factors of the SIDP accounted for about 30 per cent of the total variance of the profitability of CUEA, implying that about 70 per cent of the variance could be attributed to excluded university specific, higher education industry and external factors. However, the joint effect of the factors of the SIDP on the institution's profitability was statistically significant $(\mathrm{p}<0.05)$. Although all the factors of the SIDP had theoretically expected signs, not all had statistically significant individual (partial) effects on the profitability of CUEA. The results show that all but the null hypotheses on communication systems and personality profile of the members of the TMT were rejected at $\mathrm{p}<0.05$. The study recommended conduct of additional studies with a larger sample of universities, inclusion of the excluded variables and use of structural modeling approaches.
\end{abstract}

Keywords: strategic issue diagnosis (SIDP), internal contextual factors, top management team (TMT), profitability, factor analysis, eigenvalues, varimax rotation, regression analysis, hypothesis testing

\section{Introduction}

In recent years, the number of universities has proliferated, especially between 2012 and early 2013 when polytechnics were converted into universities. In 2014, the public higher education system in Kenya counted 22 public universities ( 15 of them established between 2012 and 2013) and 9 public university constituent colleges in $2011 .^{2}$ It also included 17 Chartered Private Universities (10 out of 17 established after 2006) and 11 Universities with Letter of Interim Authority (LIA), with the latter not being authorized to grant their own diploma/degrees (Commission for University Education, 2013). Despite the growth in the number of private institutions at higher education level, private institutions enrolled only a fraction of total students (16\% in 2012/13).

The recent phenomenal growth of the country's higher sector education has been attributed to a combination of four main factors: a rising demand for higher levels of education boosted by growing relevance of qualifications to enter and progress in the job market; a political commitment to education beyond only the basic levels and accompanying bold policy moves; key financing reforms which helped to shift the burden from households to government; and the active role of communities and the private sector in expanding supply of education services. The improvements that have occurred in gender equity have been driven through both 'bottom-up' and 'top-down' pressures. The bottom-up pressures came through women's rights groups who mobilized on a wide range of topics to move forward the gender

\footnotetext{
1 The article was extracted from the full Case Report.

2 According to Oketch (2004) there were 1 private and 1 state university in 1970/75; 8 private and 5 public universities in 1990/95; 15 private and 6 public universities in 2000/08.
} 
equity agenda at the policy level. This has been in conjunction with efforts through government ministries and global institutions to achieve gender equity throughout schooling (Unterhalter, 2012).

\section{Statement of the Problem}

The contemporary business environment for universities in Kenya is characterized by increased competition. In order to survive in this increasingly competitive industry, the universities have adopted strategic management practices to improve quality and ensure sustainability. In order to meet the challenges of the dynamic and competitive environment, the Kenyan universities are being driven by competitive forces to examine the quality of their services, to redefine their products and to measure customer satisfaction alongside improving their competitive position and performance. The universities have adopted strategic plans, business plans and ISO quality standards. However, the survival of these institutions in the contemporary competitive market environment would critically depend on the characteristics of their top management teams (TMTs) to influence strategy and performance both positively and negatively (William et el., 2006; Daniel et el., 2007; Michael, 2010; Ran, 2011; Maria and Motwani, 2009; Stephen, 2012; Markus, 2011).

Despite extensive research on decision making and substantial knowledge on issue interpretation, research has yet to focus on the factors affecting SIDP and how they, in turn, affect expected performance outcome in private universities in Kenya. Understanding the factors that shape how top managers interpret their strategic environment is critically important since such interpretations; ultimately, affect organizational actions (Dutton, Fahey \& Narayanan, 1983).Understanding interpretation - the process of translating data into knowledge and understanding - should also hold a prominent place in any attempt to understand organizational change (Daft and Weick, 1984).

Understanding the factors that shape how TMTs interpret their strategic environment is critically important since it, ultimately, affects organizational actions (Dutton et al., 1983). Through SIDP, the TMTs determine whether a significant gap exists between actual and desired results, creating a business problem. At times, the TMTs may translate this business problem into a strategic decision making problem. Clearly, SIDP deals with the early phases of strategic decision making, including identification of issues and the assessment of characteristics of these issues. The outcome of the SIDP is to give the most attention to those which entail severe consequences to the universities if they are not addressed (Heath, 1997).

\section{Research Questions}

The following research questions were used to guide the study.

a) What factors affect SIDP in private universities in Kenya?

b) To what extent do these factors affect profitability of private universities in Kenya?

c) What can be done to improve SIDP in private universities in Kenya?

\section{Literature Review}

A strategic issue is an emerging change factor in the external environment that has potential to affect an organization's ability to fulfill its strategic objectives (Julian and Ofori-Dankwa, 2008). Typical criteria used to classify an issue as 'strategic' include probable impact on the organization as whole, significant financial implications due to resources required to responding or resulting from failure to respond, and probability that the effects of the issue will be felt over several years. Strategic issues may result from legislative or regulatory action, changes in market dynamics, or other environmental jolts. Hence, SIDP refers to a structured process by which decision-makers (TMT) collectively interpret strategic issues and, subsequently, determine the organization's strategic policies, actions and responses (Julian and Ofori-Dankwa, ibid.)

There are principally two theoretical frameworks for SIDP, namely, the threat-opportunity (TO) and feasibility-urgency (FU) frameworks. The TO framework suggests that individuals use cognitive categories and linguistic labels to organize the world. Specifically, top managers appear to categorize many environmental issues as either "threats" or "opportunities" which entail different decision making processes and organizational outcomes (Dutton and Jackson, 1987; Jackson and Dutton, 1988; Chattopadhy et al., 2001).These categories are influenced by whether the issue is seen in positive or negative terms as a potential loss or gain, and as controllable or uncontrollable (Jackson and Dutton, 1988; Thomas and McDaniel, 1990).The "opportunity" label refers to "a positive situation in which gain is likely and over which one has a fair amount of control," while the "threat" label implies "a negative situation in which loss is likely and over which one has relatively little control" (Dutton and Jackson, 1987).

The FU framework, on the other hand, requires a more thorough process of decision making than the TO framework since the process requires much more effort in assessing the options (Dutton and Duncan, 1987; Julian and Ofari-Dankwa,2008).The FU framework proposes that managers should assess strategic issues by applying two dimensions, namely, urgency and feasibility. The results of the assessment affect the magnitude and type of change which an issue triggers. The dimension of urgency captures the perceived importance of taking action on an issue and 
the perceived cost of not taking an action (Dutton and Duncan, 1987). Assessment of urgency depends on the saliency of an issue, perceived time pressure, visibility of an issue, judgment of decision makers' responsibilities for the occurrence of the issue. The second dimension of feasibility reflects TMT's judgment about the possibility of resolving an issue (Dutton and Duncan, 1987; Ginsberg and Venkatraman, 1995). Evaluation of the feasibility dimension involves the judgment of issue understandability and issue capability, with the former capturing the extent to which decision making can identify means for resolving the issue and the latter indicating the extent to which the means for resolving issues are available and accessible.

Extensive literature abounds on the interaction among the factors affecting the SIDP (independent variables), environmental factors (moderating variables) and organizational performance (dependent variables). The interaction among the three sets of variables is summarized in Figure 1. Borrowing from organizational theories, management theory, cognitive psychological and operations management, personality theory and information literature, the determinants of the SIDP include organizational structure (Miller, 1987; Drazin and Howard, 1984), organizational strategy (Hambrick, 1981; Meyer, 1982), organizational culture (Schein, 1985; Thompson and Wildausky, 1986), top management characteristics (William et el., 2006; Daniel et el., 2007; Gallen'n, 2009; Ran, 2011), decision -specific characteristics (Dean and b Sharfman, 1993; Dutton, 1986), ICT infrastructure ( Ansof, 1991; Pitt, 2005; Jackson, 1996, 1997).

It has become increasingly important for organizations to develop systems of performance measurement which not only reflect the growing complexity of the business environment but also monitor their strategic response to this complexity (Johnson, 2005; Neely et al., 1996).The main rationale for measuring an organizations performance is to be able to manage it. Performance measurements can be used as a tool for evaluating an organization's strategy (Kaplan and Norton, 1996). They are used to, translate an organization's strategy into corporate objectives, guide and focus employees' efforts. To control whether or not the strategic objectives are reached, a double - loop learning is used to challenge the validity of the strategy itself, and visualize how individual employees' efforts contribute to the overall business objectives (Neely, 1998; Simons, 2000)

Performance measurement is usually carried out using performance measurement system, which consists of several individual measures. The most commonly used performance model is the Balanced Scorecard (BSC). Under this model, measures for performance are based on an organization's vision and strategy (Kaplan and Norton, 1996). Measures are chosen to measure success factors from different points of view, such as that of customers, employees, business process, and financial success, as well as from point of view of past, current, and future performance. This way, all aspects of an organization's performance can be measured and managed.

Finally, like other standard processes, the effect of SIDP factors on organizational performance is moderated by environmental factors including political-legal environment, economic environment, socio-cultural environment, technological environment and competition.

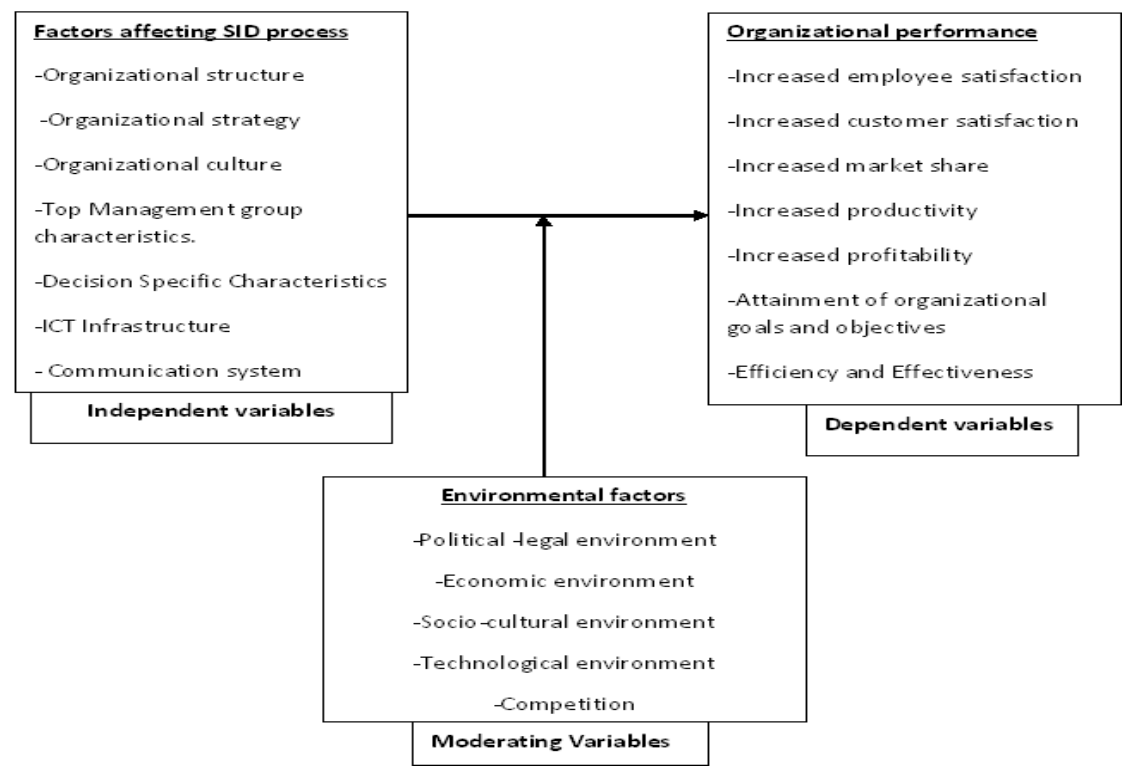

Figure 1. Conceptual Framework

Along with the increased interest in strategic, managerial and organizational cognition over the last decade (Meindl et al., 1994; Porac et al., 1996; Swenk, 1988; Walsh, 1995), a growing body of research by Dutton, et el. (1987) has paid particular attention to SIDP. Within the SIDP literature, most research has focused on how individuals in top 
management teams cognitively interpret and behaviorally respond to strategic issues in their environment and how this affects the elaboration and implementation of organizational strategic responses (Daft and Weick, 1984; Dutton and Jackson, 1987; Dutton \& Duncan, 1987; Gioia and Chittepedi, 1991; Milliken, 1990; Schneider, 1994; Thomas and McDaniel, 1990; Thomas et al., 1997).

Further research on strategic issues and issue management systems has been focused on strategic issue diagnosis (Dutton et al.,1983);strategic issue categorization (Dutton et al.,1987b);forms, functions and contexts of SIMS (Dutton et al.,1987d);the role of uncertainty and feasibility on the patterns of interest around issues (Dutton et al.,1988); discerning threats and opportunities (Jackson et al.,1988) and selling issues to top management (Dutton et al.,1993).

\subsection{Review of Empirical Evidence}

Knight and McDaniel (1979) suggested that information processing structures (IPS) influences top managers' interpretations of strategic issues. The way a top management team is structured to process information about strategic issue limits or enhances recognition of issue stimuli, impedes the search for data and mutes causal relationships associated with an issue (Staw et al., 1981).

Katz (1982) empirically demonstrated and supported arguments that the length of top management tenure lowers the likelihood of organizational and strategic change. He further stressed that organizational tenure was associated with increased commitment by top managers to their organizations established policies and practices. Hambrick (1990) equally demonstrated and found a negative relationship between top management organization tenure and strategic change.

Hambrick and Masons (1984) widely studied upper echelons theory and proposed that top manager's background, demographics, and experience are important influencers on psychological and cognitive 'givens' that shape their strategic decisions. This, in turn, will influence outcome of their actions taken in organizations. Eisenhardt (1989) found that management teams with the capacity to access and process information about strategic issues can cope with stress and anxiety. These teams impart a sense of mastery and control to decision makers, since the executives feel they have surveyed and processed the needed information.

Milliken (1990) showed that participation in strategic decision making responsibilities allows top managers to be exposed to the opinions of others who may be more active than others. Structural characteristics such as high levels of participation and interaction and low level of formalization were found to be conducive to a high level of information processing and facilitated extensive use of information.

Thomas and McDaniel (1990) examined how the top management team (TMT) information processing structure and strategy were related to managers' information usage and affect performance. In their study of 151 hospital top managers, they found that TMT information processing structures were positively related to information usage with potential positive gain and controllability of interpretations. The findings also indicated that both strategy and IPS are related to how chief executives label strategic situations and range of variables they use during their interpretations. Sutcliffe (1994), on the other hand, found a negative association between work history diversity and accurate detection of information related to the level of resources available in an organization's environment. Her results suggested that team interactions or other communication processes are represented in more diverse teams and this hinders the sharing of certain types of information among members.

Jackson and Dutton (1988) found that top managers perceive threats as having a clear negative connotation, as likely to bring loss without gain, and as associated with feeling of low control. They also revealed that top managers perceive opportunities as positive, as having a high potential to bring gain and as associated with feeling of control.

Goh and Ryan (2000), from a sample of for-profit Canadian companies, revealed that learning capability was positively related to a non- financial performance measure, job satisfaction. Size of firm was found to be negatively correlated with learning capability. An unexpected finding of the study was that formalization or bureaucratization has a significantly positive relationship to two financial performance indicators, namely, return on equity (ROE) and return on assets (ROA).

Kumar and Subramanian (2002) found that hospitals with strong customer focus have significantly higher performance in terms of success of new services and facilities and ability to retain patients. A study of 398 schools in Estonian secondary schools by Vadi (2003) revealed that managing and improving organizational culture contributes to the performance of schools. A study by Fuschs and Woessmann (2004), using international data from the programmer for International Students Assessment, revealed that the bivariate correlation between the availability of ICT and students performance is strongly and significantly positive.

Abdullah et al.( 2008) studied managers' perceptions in 255 electrical and electronic (E\&E) firms in malysia on 
influence of soft factors on quality improvements and performance. Their results indicated that organizational performance was significantly influenced by management commitment, customer focus, and employment involvement.

In their study, Liu and Mailtis (2009) found out that issue type influences the emotions triggered in TMT strategizing discussions, and that it was consistent with SIDP literature. The research argued that strategic issues, because of their magnitude of gain and loss associated with them, are likely to garner more attention and generate more emotions in their discussion (Dutton and Dukerich, 1991; Dutton and Duncan, 1987; Dutton and Jackson, 1989). Existing literature also shows that emotions are likely to be generated around issues that require a decision and are expected to have an impact on an individual's or group's concern. Furthemore, the kind of emotion generated is likely to depend on whether an issue is perceived as an opportunity or a threat (Dutton and Jackson, 1987). In sum, issues that are strategic, have a direct impact and require an immediate decision trigger, more emotions than other issues, and the kind of emotion triggered will be influenced by team member construction of the issue as either threat or opportunity. The emotion, initially, triggered by issue type and, in turn, creates the foundation for the emotional dynamics that develop in a team member's interaction.

Barr and Glynn (2004) investigated cultural variations in the strategic issue labels of threat and opportunities using a survey of 276 American and international respondents. Overall, their findings indicate that perceptions of controllability in discriminating threats and opportunities exhibited cultural variations in accord with the culture placed on uncertainty avoidance (UA).They found that UA affects the degree to which individuals associate controllability attribute with threats and opportunities. As expected, this association is significantly stronger for individuals from high UA culture than from low UA cultures when it comes to associating the lack of controllability with threat. High UA culture, on the other hand, is more strongly associated the presence of controllability with opportunity. No significant associations were found for the other cultural values of power distance, individualism, and masculinity (Hofstede, 1980).

Papadakis (1995 investigated impact of perceived decision specific characteristics on the process followed in making strategic decisions. He found that the magnitude of impact was positively associated with rationality, hierarchical decentralization and lateral communication, while it was negatively related to the rule of formalization. Threat/crisis was positively related to politicization i.e. the issue in question may become a vehicle for political battles among participants. Strategic decisions perceived as pressure situations were positively related to rule of formalization and problem solving dissension, while they were negatively related to hierarchical centralization. Crisis situations led to high politicization. Frequency/familiarity issues tend to attract interests from various departments in the company (significant coefficient with lateral communication). Umokoro (2009) investigated the extent to which top management group characteristics interact with either organizational performance in order to bring about strategic change. The Study revealed that there is an inevitable interaction between performance and role played by organizations TMT in encouraging or inhibiting strategic change.

Although numerous studies have been conducted to explore the relationship between the factors of the SIDP, empirical findings seem to be mixed and inconclusive (Carpentern, 2011). For example, though well theoretically premised under the upper echelon theory, empirical evidence on effects of the top management team (TMT) demographic characteristics (i.e. age, functional background, gender, tenure, and educational background) on organizational performance is mixed (Hambrick and Mason, 1984). While William et el. (2006) validated the proposition of the upper echelon theory that TMT demographic characteristics have overall significant positive correlation with performance, the results of the studies with individual demographic characteristics are mixed and inconclusive.

While Akie et el. (2005), Khutula (2011), Carman (2005) and Ran (2011) validated a positive correlation between education and strategy and performance, Thomas et el. (2004) found that while education is positively correlated with differentiation strategy, it is negatively correlated with cost-leadership strategy. Nandakumar et el. (2011) also could not confirm a strong correlation between education and both the differentiation and cost-leadership strategies. While Stephen (2012) finds a negative correlation between age and organizational performance, Irene et el. (2008) found a positive effect of age on performance. While Stephen (ibid.) and Shamsie (2001) found a strong positive association between TMT tenure and performance, William et el. (2006) and Hambrick (2007) found a negative relation. However no study has either confirmed or contradicted the findings by Zheng (2012), Zhao et el. (2013), and Liquin et el. (2002) showing positive correlation between the degree of female participation and firm performance in Chinese privately owned firms.

Again, although numerous studies have been conducted to explore the relationship between organisational culture and performance, empirical findings seem to be mixed and inconclusive. Contrary to theoretical predictions, Yesil and Kaya (2013) found that organisational culture dimensions have no effect on firm financial performance. The finding was attributed to the limitations of the study, suggesting a need for further studies to provide conclusive results. Olanipekun and Abiola (2013), on the other hand, found that organizational culture positively affects organizational performance.

The mixed and inconclusiveness of past studies investigating relationship between SDP factors (i.e. organizational 
culture, structure, strategy) and organizational performance has largely been attributed to four methodological weaknesses. First, these studies fail to control for mediating context specific variables including practices of knowledge management , environmental national contexts , firm size, ownership status, and organizational capabilities (Zheng et el., 2009; Elbana, 2011) ), which can influence organizational performance. Second, the studies are based on small sample or case study explorations (e.g. Al-Ghamdi, 1998). There exists very limited large-scale empirical study attempting to quantitatively assess the influence of the context specific control variables. Thirdly, the past studies have lacked an integrative framework for the four basic antecedent factor affecting the SIDP and performance, namely, TMT characteristics, the decision-specific characteristics, environmental characteristics, and the firm's characteristics.

Finally, most of the past studies have used basic correlation and/or reduced-form regression analysis to test the theoretical predictions of the SIDP on organizational performance. Few or no studies have used structural- form empirical methodology that is premised on structural (behavioral) economic model which, in turn, serves to interpret the estimated data.

\section{Methodology}

\subsection{Research Design}

This study adopted an explanatory non-experimental survey research design to investigate the internal contextual organizational factors affecting SID and their implications on organizational profitability. Explanatory research seeks to establish causal relationship between variables (Saunders et al., 2009 \& Robson 2002). Kerlinger and Lee (2000) assert that an explanatory non-experimental research design is appropriate where the study is attempting to explain how the phenomenon operates by identifying the underlying factors that produce change without manipulation of the independent variable(s).

\subsection{Target Population}

Target population of the study was top management team (TMT) of CUEA. It consisted of Senior management (chancellor, vice chancellor, deputy vice chancellor (DVC) administration, DVC academic affairs), middle level management (faculty heads i.e. Deans) and operational management (heads' of departments (HOD's), directors). There were approximately fifty (50) members of TMT

\subsection{Sampling}

Owing to the small size of the population, a census survey design was preferred to sampling. Hence, the entire TMT was selected to participate in the study. However, only one branch of the university was considered i.e. the main campus which is its headquarters and is located in Langata, Nairobi. The selection of the main campus was based on the fact that more than $95 \%$ of the university's TMT is resident here.

\subsection{Data Collection}

The study used both primary data and secondary data. The primary data was collected using a self- administered questionnaire. The questionnaire was pilot tested on a few members of TMT before being rolled out. This facilitated detection and correction of any errors. The secondary data was obtained from two main sources, namely, document analysis and Internet databases. The document analysis involved perusing information from the university's documents such as Staff Handbook, Annual Financial Reports, human resource reports, brochures, and others with relevant information. Information obtained from web involved reviewing data published including e-books, e-journals, articles

\subsection{Data Analysis}

\subsubsection{Empirical Model}

The following regression model was adopted for the study:

$$
\mathrm{Y}_{\mathrm{i}}=\beta_{0}+\beta_{1} \mathrm{X}_{1 \mathrm{i}}+\beta_{2} \mathrm{X}_{2 \mathrm{i}}+\beta_{3} \mathrm{X}_{3 \mathrm{i}}+\beta_{4} \mathrm{X}_{4 \mathrm{i}}+\beta_{5} \mathrm{X}_{5 \mathrm{i}}+\beta_{6} \mathrm{X}_{6 \mathrm{i}}+\beta_{7} \mathrm{X}_{7 \mathrm{i}}+\varepsilon_{\mathrm{i} ; \mathrm{i}}=1,2,3 \ldots, \mathrm{n}
$$

Where;

$\mathrm{Y}=$ organizational profitability.

$\mathrm{X}_{1}=$ Organizational culture

$\mathrm{X}_{2}=$ Communication system

$\mathrm{X}_{3}=$ Personality profile of TMT

$\mathrm{X}_{4}=$ Organizational structure

$\mathrm{X}_{5}=$ Organizational strategy

$\mathrm{X}_{6}=\mathrm{ICT}$ infrastructure 
$\beta_{0}=$ Constant term

$\beta_{\mathrm{i}}$ 's = Coefficients of the explanatory variables

$\varepsilon_{\mathrm{i}=}$ Unobserved random error term $\left(\varepsilon_{\mathrm{i}}\right.$ is assumed to be IIID)

The eight null hypotheses were formulated thus;

H1: $\mathrm{B}_{1}=\mathrm{B}_{2}=\mathrm{B}_{3}=\mathrm{B}_{4}=\mathrm{B}_{5}=\mathrm{B} 6=0$ (i.e. All the explanatory factors have statistically insignificant joint effect on profitability)

H2: $B 1=0$ (i.e. Organizational culture has statistically insignificant effect on profitability)

H3: B2 $=0$ (i.e. Communication system has statistically insignificant effect on profitability)

H4: B3=0 (i.e. Personality profile of TMT has statistically insignificant effect on profitability)

H5: B4=0 (i.e. Organizational structure statistically insignificant effect on profitability)

H6: B5=0 (i.e. Organizational strategy has statistically insignificant effect on profitability)

H7: B6=0 (i.e. ICT infrastructure has statistically insignificant effect on profitability)

Prior to the estimation of the specified regression model, the collected data was subjected to factor analysis (data reduction) using principal components and varimax (orthogonal) rotation to reduce numerous independent variables in the SIDP and organization performance. The results of the factor analysis were then used to estimate the specified regression model. Specifically, the performance factor with the highest rotational loadings was regressed against the factor analysis results of the SIDP. The resulting multiple regression estimation results will be tested for both joint and independent (partial) statistical significance.

\section{Empirical Results}

\subsection{Factor Analysis Results}

The factor extraction results for the SIDP were summarized in Appendix 2. They reveal that six variables (with eigenvalues greater than one) accounted for about $75 \%$ of the total variance in the SIDP. Hence, out of the 29 initial factors of the SIDP we only retained six. The results of the varimax (orthogonal) rotation were presented in Appendix 3.Like previous studies, they showed that the variables in the SIDP tended to cluster on six factors, namely, as organizational culture, communication system, and personality profile of the members of the TMT, organizational structure, organizational strategy and ICT system.

The factor extraction results of the organizational performance of CUEA were presented in Appendix 4. They reveal that three variables (with eigenvalues greater than one) accounted for about $72 \%$ of the total variance of the organizational performance. Hence, out of the 10 initial factors of the organizational performance we only retained three. The results of the varimax (orthogonal) rotation were presented in Appendix 5. Again, like previous studies, they showed that the variables in the organizational performance tended to cluster on three factors, namely, profitability, customer satisfaction and number of graduates.

\subsection{Regression analysis Results}

The specified regression model was estimated with ordinary least squares (OLS) using the results of the factor analysis of the SIDP in CUEA. The overall results of the regression model estimation are presented in Table 1.

Table 1. ANOVA results of the effect of the 6 factors on Organizational profitability

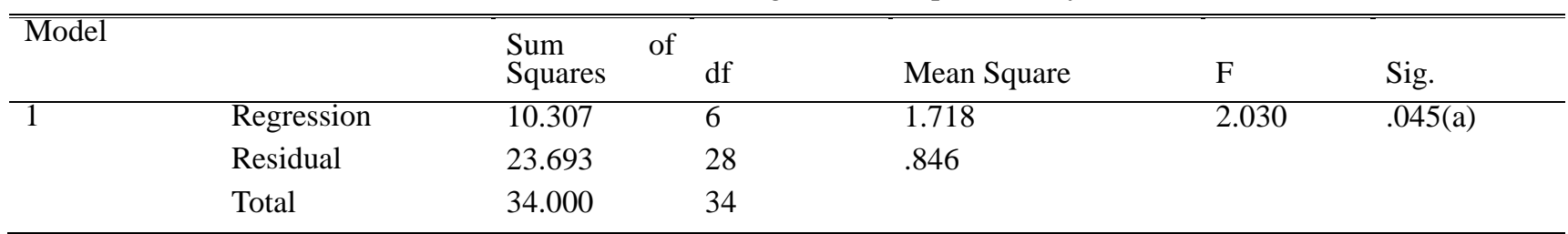

The results show that the joint effect of the six factors of the SIDP (i.e. organizational culture, communication systems, personality traits of managers, structure, strategy, and ICT systems) accounted for about 30 per cent of the total variance of the profitability of CUEA. This implies that about 70 per cent of the variance of the profitability of CUEA was accounted for by other determinants. However, the joint effect of the factors of the SIDP on the institution's profitability was statistically significant $(\mathrm{p}<0.05)$. Hence, we rejected the null hypothesis that the joint effect of the six factors of the SIDP on profitability was zero or purely random. The results of the regression model estimation coefficients are presented in table 2. 
Table 2. Coefficients of the predictors of organizational profitability

\begin{tabular}{|c|c|c|c|c|c|c|}
\hline \multirow[t]{2}{*}{ Model } & & \multicolumn{2}{|c|}{$\begin{array}{l}\text { Unstandardized } \\
\text { Coefficients }\end{array}$} & \multirow{2}{*}{$\begin{array}{l}\text { Standardized } \\
\text { Coefficients } \\
\text { Beta }\end{array}$} & \multirow[t]{2}{*}{$\mathrm{t}$} & \multirow[t]{2}{*}{ Sig. } \\
\hline & & B & Std. Error & & & \\
\hline \multirow[t]{6}{*}{1} & (Constant) & ${ }_{6}^{1.170 \mathrm{E}-1}$ & .155 & & .000 & 0.050 \\
\hline & $\begin{array}{l}\text { Organizational } \\
\text { Culture }\end{array}$ & -.058 & .158 & -.058 & -.365 & .718 \\
\hline & $\begin{array}{l}\text { Communication } \\
\text { systems }\end{array}$ & .370 & .158 & .370 & 2.343 & .026 \\
\hline & $\begin{array}{l}\text { Personality profile } \\
\text { Organizational }\end{array}$ & .355 & .158 & .355 & 2.253 & .032 \\
\hline & $\begin{array}{l}\text { structure } \\
\text { Organizational } \\
\text { strategy }\end{array}$ & .091 & .158 & .091 & .580 & .567 \\
\hline & ICT syctems & $\begin{array}{l}.091 \\
142\end{array}$ & $\begin{array}{l}.158 \\
158\end{array}$ & $\begin{array}{l}.091 \\
142\end{array}$ & .576 & .569 \\
\hline
\end{tabular}

Although all the factors of the SIDP had theoretically expected signs, not all had statistically significant individual (partial) effects on the profitability of CUEA. Empirical results of the tests of the null hypotheses of the individual effects of the determinants at $\mathrm{p}<0.05$ is summarized in Table 3 .

Table 3. Empirical Results of Tests of Hypotheses

\begin{tabular}{ll}
\hline Factor & Decision \\
\hline Joint effect of all factors & Reject H1 \\
Organizational culture & Accept H2 \\
Communication systems & Reject H3 \\
Personality profile of TMT & Reject H4 \\
Organizational structure & Accept H5 \\
Organization strategy & Accept H6 \\
ICT systems & Accept H7
\end{tabular}

The results show that all but the null hypotheses on communication systems and personality profile of the members of the TMT were rejected at $\mathrm{p}<0.05$. These factors of the SIDP had statistically significant positive effect on the profitability of CUEA. Hence, the finding of the study reaffirms the findings of previous studies on critical role of these two factors on organizational performance. The null hypotheses on organizational culture, organizational structure, organizational strategy and ICT systems could not be rejected at $\mathrm{p}<0.05$.

The mixed and rather disappointing findings of this study could be attributed to the exclusion of key university-specific , higher education industry level and macroeconomic control variables and weaknesses in the methodological adopted to analyse the data. By focusing on only six internal contextual factors of the SIDP, the study excluded university specific control variables like size, ownership status (i.e. wholly local, wholly foreign or mixed ownership, and extent of government participation), and governance. The study did not include such industry level control variables like market structure/market power and shifts in regulatory regime. The study did not also include such key macroeconomic control variables as economic growth, inflation and exchange rate, all of which of which have important moderating impact on the profitability of private universities in Kenya. The exclusion of these key control variables not only explain the low overall explanatory performance of the estimated model but also complicates the accuracy of the interpretations of the estimated coefficients.

The non-rejection of the null hypotheses of most of the determinants in the study was also attributed to possible methodological weaknesses of data analysis. The study employed reduced-form regression model rather than the structural- form empirical methodology that is premised on structural (behavioral) economic model which, in turn, serves to interpret the results the estimated coefficent. Hence, the conceptual framework underpinning the study was only partially implemented without control for the moderating variables. Further studies should attempt to model the conceptual framework structurally and estimate it using appropriate software (s).

Furthermore, the use of OLS estimation technique of the specified regression model was not underpinned by diagnostic parametric tests of the classical linear regression model assumptions of the normality of the residuals, heteroscedasticity, multicollinearity and autocorrelation.

\subsection{Results of Suggestions for Improvement of SIDP in CUEA}

The results of the suggestions for improving the SIDP in the institution were presented in Appendix 6. Over 70\% of the respondents suggested that the management should ensure good planning, administration, and control of ICT 
infrastructure. Over $70 \%$ of the respondents also strongly agreed that TMT should ensure that the institution's organizational structure fits its goals and objectives and that they should ensure that suitable resources with right skills and competencies are produced and retained to undertake necessary roles in the organization.

\subsection{Conclusions}

The proliferation of universities, especially between 2012 and early 2013 when polytechnics were converted into universities has not only improved access to higher education in the country but also increased competition among the universities for students. It is estimated that there are about sixty universities in the country. These comprise public and private universities at various registration stages with the Commission for University Education (CUE). With the phenomenal growth in the number of universities, GER at higher education has more than quadrupled. The number of students enrolling in higher education grew by more than $60 \%$ over 5 years with about $20 \%$ of university students being enrolled in private institutions in 2010/11.

The contemporary business environment for universities in Kenya is characterized by increased competition. In order to survive in this increasingly competitive industry, the universities have adopted strategic management practices to improve quality and ensure sustainability. These practices have included the adoption strategic plans, business plans and ISO quality standards. Understanding the factors affecting the SIDP and how these factors, in turn, affected the profitability of these universities remains the focus of contemporary strategic management empirical literature.

The findings showed that respondents were aware of the factors affecting SIDP; this included organizational culture, communication systems, personality profile of managers, strategy and structure. The respondents were also aware of the impact these factors have on the institution's profitability. The most significant indicators of organizational performance in this study were profitability of the organization. Consistent with past studies, six factors, namely, organizational culture, communication, personality profile of the members of TMT, organizational structure, organizational strategy and ICT infrastructure were identified as affecting both the SIDP and profitability of CUEA. The suggestions for improving the institution's SIDP and, hence, on the institution's profitability also revolved around the four factors. These were identified as correctly analyzing existing culture, ensure organizational culture fits company's goals and objectives, ensure good planning, administration and control of ICT infrastructure etc.

\section{Recommendations}

Based on the conclusions, the study made the following recommendations to improve both the SIDP and its impact on profitability in CUEA and on future similar studies.

i) Management should ensure good planning, administration, and control of ICT infrastructure; align organizational structure with the institution's goals and objectives; and should ensure that suitable resources with right skills and competencies are produced and retained in order to undertake necessary roles in the organization.

ii) CUEA should develop programs for monitoring and evaluating SIDP in relation to performance indicators. TMT should come up with ways of identifying the factors that affect SIDP and also identify strategic responses. The organization can implement new policies and procedures to guide SIDP. Improvements in working conditions of TMT, fostering team work, realigning strategy to fit with goals and objectives, acquire new ICT systems, rewarding employees for success, and conflict resolution etc. can also be implemented. CUEA should also benchmark its SIDP with other institutions.

iii) Further studies should be conducted with a representative sample of public and private universities. The focus of this study on only one private university (CUEA), clearly, limits the extent to which the results could be generalized to all universities, in general, and private universities, in particular. It is estimated that there about thirty three (33) private universities in Kenya.

iv) Further studies should employ structural- form empirical methodology that is premised on structural (behavioral) economic model which, in turn, serves to facilitate proper interpretation of the estimated results. Even the reduced-form regression model employed in the study only partially captured the conceptual framework posited for the study. The regression model only captured the internal organizational contextual factors that have an effect on SIDP and their impact on organizational profitability. Specifically, the empirical model did not control for the effects of the intervening variables. In this regard, further studies should include additional firm (university) -specific, industry (higher education)-specific, and external (macroeconomic industry-specific and governance) factors.

\section{References}

Abdullah, M., Uli, J., \& Tari, J. (2008). The influence of soft factors on quality improvement and performance: perception from managers". Total Quality Management Journal, 20(5).

Aidla, A., \& Vadi, M. (2003). Relationship between organizational culture and performance in Estonian schools with regards to location and size, Administrative Science Quarterly, 1(3). 
Akie, I., Park, J. W., Supriyadi, F., \& Yang, H. (2012). (1980). 'Integrating relative standing and market discipline: A complexity theory perspective of post-merger and acquisition Eexecutive departure' in Finkelstein, S. and Cooper, C. L. (ed). Advances in mergers and acquisitions (Advances in mergers and acquisitions, Vol. II), Emerald Publishing Limited, 181-197.

Ansoff, H. (1980). Strategic issue management, Strategic Management Journal, 1(2), 131-148.

Ansoff, H. (1991). Strategic management in historical perspective.International Review of Strategic Management Strategic Management Journal, 2, 449-461.

Ansoff, H., \& McDonnel, E. (1990). Implementing strategic management. Prentice hall.

Barr, S., \& Glynn, A. (2004). 'Cultural variations in strategic issues interpretation: relating cultural uncertainty avoidance to controllability in discriminating threat and opportunity.' Strategic Management Journal, 25(1).

Bower, J. (1970). Managing the resource allocation process. Cambridge, mass. Harvard university press.

Camelo, M. C., Hernandez, A. B., \& Valle R. (2005), 'The relationship between top management teams and innovative capacity in companies', Journal of Management Development, 24, 683 - 706.

Camillus, J., \& Datta, D. (1991). 'Managing strategic issues in a turbulent environment.' Long range planning, 24(2), 67-74.

Caplow, T. (1976). How to run any organization. New York: Harper Collins.

Carpenter, M. A. (2011). The Handbook of Research on Top Management Teams, Research Handbooks in Business and Management Series

Chattopadhyay, P. Glick, W., \& Huber, G. (2001). 'Organizational actions in response to threats and opportunities. 'Academy of Management Journal.

Colclough, C., \& Webb, A. (2010) 'The Impact of Aid on Education Policy in Kenya' RECOUP Working Paper Series, No. 36, Cambridge, UK.

Daft, R., \& Lengal, R. (1986). 'Organizational information requirements, media richness, and structural design'. Management Science, Vol. 32.

Daft, R., \& Weick, k. (1984). 'Towards a model of organizations as interpretation systems'. Academy of Management Review, 19, 284-295.

Davenport, H. (1993). Process innovation, Harvard business school press, Boston MA.

Duncan, R., \& Weiss, a (1979). 'Organization learning. Implications for Organization Design'.

Dutton, J \& Ottensmeyer, S. (1987). 'Strategic issue management systems: forms, functions and contexts.'Academy of Management Review, 12(2), 355-365.

Dutton, J., \& Ashford, S. (1993).Selling issue to top management. Academy of management review, 18(5), $407-423$.

Dutton, J., \& Dukerich (1991). 'Keeping an eye on the mirror: The role of image and identity in organization adaptation'. Academy Of Management Journal, 34.

Dutton, J., \& Duncan, R. (1987). 'The creation of momentum for change through process of strategic issue management'. Strategic Management Journals, 8(3).

Dutton, J., \& Duncan, R. (1987b).'The influence of strategic planning process on strategic change'. Strategic management journal, 4.

Dutton, J., \& Jackson, S. (1987). 'Categorizing strategic issues; links to organizational action'. Academy of Management Review, 12(1), 279-295.

Dutton, J. (1986). The processing of crisis and non- crisis strategic issues: A situationalist perspective.' journal of management studies, 23(5), 502-515.

Dutton, J. (1993).'Interpretation on Automatic: A different view of strategic issue diagnoses. Journal of Management Studies, 3(3), 339-354.

Dutton, J., Fahey, L., \& Narayanan, V. (1983). 'Towards understanding strategic issue diagnosis'. Strategic Management Journal, 4, 307-323.

Edelman, M. (1977). Political language: words that succeed and policies that fail. Newyork, Academic press.

Elbama, S. (2011). 'Mult-theoretic perspective of strategy processes'. UAEU-FBE- Working Paper Series.

Fieldman, M., \& March, J. (1981).'Information in organizations as signal and symbol'. Administrative Science 
Quarterly, 26.

Fieldman, M., \& March, J. (1981).'Information in organizations as signal and symbol'. Administrative Science Quarterly, 26.

Finkelstein et el, (2009). Strategic Leadership: Theory and Research on Executives, Top Management, Teams, and Boards, Strategic Management Series, Oxford University Press. Oxford.

Finkelstein, S., Hambrick, D. C., \& Cannella, A. A. (2012). 'A review of the relationship between female participation in TMT and Corporate Governance,' Economic Management Journal, 2012-01

Fiol, M., \& Lyles, M. (1985). 'Organizational learning'. Academy of management Review, Vol.10.

Frederickson, J. (1986). 'The strategic decision process and organizational structure'. Academy of Management Review, 1(2).

Fuchs, T., \& Woessmann, L. (2004). 'Computers and learning: Bivariate and multivariate evidence on the availability and use of computers at home and at school', CEsifo working paper, 1321.

Gass, S. (1985). Decision making models and Algorithms. Wiley interscence publication, john wiley and sons.

Ginsberg, A., \& Venatraman, N. (1995).'Institutional initiatives for technological change: from issue interpretation to strategic choice'. Organizational Studies, 16(3).

Gioia, D., \& Thomas, B. (1996). 'Identity, image, and issue interpretation: sense making during strategic change in academia.' Administrative Science Quarterly. Cornel University, Johnson graduate school.

Hambrick, D., \& Brandon, G. (1988). 'Executive Values'. In D. Hambrick (Ed), The executive effect: concepts and methods for studying to managers. Greenwich, C: JAI.

Hambrick, D., \& Finkelstein S. (1987). 'Managerial discretion: Abridge between polar views or organizational outcomes'. Research in organizational behavior, 9, CT: JAI.

Hambrick, D., \& Mason, P (1981). 'Upper echelons: The organization as a reflection of its top managers'. Academy of Management Review, 9.

Hambrick, D. (1981).'Environment, strategy and power within top management teams'. Administrative Science Quarterly, 26.

Hambrick, D. (1982). 'Environmental scanning and organizational strategy.' Strategic Management journal, 3(2), 159-174.

Hambrick, D. (1994). 'Top management groups: A conceptual integration and reconsideration of the "team" label'. Research in organizational Behavior, 16.

Hambrick, D. C., \& Mason, P. A. (1984). "Upper echelons: the organizations reflection of its top managers", Academy of Management Review, 9, 193 -206.

Hannan, M., \& Freeman, J. (1984). 'Structural inertia and organizational change'. American sociological Review, 29.

Herrmann, D., \& Datta, K. (2005), "Relationships between top management team characteristics and international diversification: an empirical investigation", British Journal of management, 16, 69-78.

Hofstede, G. (1993). Cultures and organizations software of the mind. Newyork: McGraw hill.

Holt, K. (2006). Strategic issue diagnosis identifies risk, opportunities. Hotel \& Motel Management, 211(5), 23-24.

Huber, P., \& Daft, L. (1987). 'The information environment of organizations. Handbook of organizational communication': An interdisciplinary perspective, Newbury park, CA: sage.

Irene,G., Nancy, B., Brown, J., \& Abdul, A. R. (2008). 'Top management team demographic characteristics, business strategy, and firm performance in the US airline industry: The role of managerial discretion', Management Decision, 46(2), 201-222.

Jackson, S., \& Dutton, J. (1988). 'Discerning threats and opportunities. Administrative Science Quarterly, 33, 307-387.

Julian, S., \& Ofori - Dankwa, J (2008). Towards an integrative cartography of two strategic issue diagnosis frameworks. 'Strategic Management Journal, 29, 93-114.

Kaplan, R., \& Norton, D. (1996). The balanced scorecard. Translating strategy into action. Harvard business school press, Boston, Massachusetts.

Katz, R. (1992). Time and work: Towards an integrative perspective. ', Greenwich, JAI press.

Keller, G. (1983). Academic Strategy. The management revolution in America higher education. Baltimore: johns 
Hopkins University press.

Khutula Sibanda, Ronel Erwee, \& Eric Ng (2011). 'Differences between high - and low - performing exporting firms in a developing country', in Shaoming Zou Huifen Fu (ed.) International Marketing (Advances in International Marketing, Volume 21), Emerlad Group Publishing Limited, 207-228.

KNBS (2011). Economic Survey 2011, Nairobi.

Knight, E., \& McDaniel, R. (1979). Organizations: An information systems perspective, Belmont, CA: wadworth.

Lawrence, P., \& Lorsch, J. (1967). Differentiation and integration in complex organizations. Journal of Administrative Science Quarterly, 12, 1-30.

Leifer, R., \& Huber, G (1977). 'Relations among perceived environmental uncertainty. Organizational structure, and boundary - spanning behavior'. Administrative Science Quarterly, 22.

Liquin, W., \& Zhihui (2002). 'Empirical study on the Relationship between Characteristics of TMTs and Firm Performance of Chinese Business', Nankai Business Review

Lyles, M. (1981). 'Formulating strategic problems. Empirical analysis and model development'. Strategic Management Journal, 2,

Maria, \& Motwani (2009). 'Top management team and corporate performance: a study of Greek firms', Team Performance management, 14(7), 340-363

market discipline: A complexity theory perspective of post-merger and acquisition Eexecutive departure' in Finkelstein, S. and Cooper, C. L. (ed). Advances in mergers and acquisitions (Advances in mergers and acquisitions, Vol. II), Emerald Publishing Limited, 181-197.

Meindl, J. Stubbart, C., \& Porac, J. (1994). 'Cognition within and between organizations,' Organizational Science Quarterly, 5(4).

Meyer, A. (1982). 'Adapting to environmental jolts'. Administrative Quarterly, 27, 515-538.

Michael A. A. (2010). 'Top team composition and corporate turnaround under environmental stability and turbulence', Leadership \& Organization Development Journal, 31(3), 196-212.

Miles, R., \& Snow, C. (1978). Organizational strategy, structure, and process. Academy of Management Review, 3, 546-562.

Miller, D. (1987). 'Strategy making and structure: Analysis and implications for performance'. Academy of Management Journal, 30.

Milliken, F. (1990). 'Perceiving and interpreting environmental change: An examination of collage administrators' interpretation of change demographics'. Academy of Management Journal, 33, 42-63.

Mintzberg, H. (1983). Power in and around organizations. Englewood cliffs, N.J.: Prentice hall.

Mintzeberg, H., Raisinghani, D., \& Theoret, A. (1976).'The structure of unstructured decision processes'. Administrative Science Quarterly, 21, 246-275.

Moore, B. (1979). 'Planning for emerging issues'. Public Relations Journal, 35(11).

Nandakumar, M. K., Ghobadian, A., \& O'Regan, N. (2011). 'Generic strategies and performance - evidence from manufacturing firms', International Journal of Productivity and Performance Management, 60(3), 222-251.

Neely, M. (1998). Measuring business performance. Why, what, and how? Profile books limited, London.

Neely, M., Mills, J., Gregory, M., Richards, H., Plattas, K., \& Bourner, M. (1996) Getting the measure of your business: Finlay, London.

Ngolovoi, M. S. (2008), 'Financing Higher Education in Kenya: Student Perceptions and Experiences', Tertiary Education and Management, 14(2), 141-150.

O’Reilley, C., Caldwel, D., \& Barnett, W. (1989). 'Work group demography, social integration, and turnover'. Administrative Science Quarterly, 34.

Olanipekun, O.A., Aje, O., Abiola, J.O., \& Falemu, D. (2013). 'Effects of Organizational culture on the performance of quantity surveying firms', International Journal of Humanities and Social Sciences, 3(5).

Otieno, W. (2010) 'Kenya' in Pillay, P. (2010) Higher Education Financing in East and Southern Africa, Centre for Higher Education Transformation, Cape Town.

Pfeiffer, J., \& Salanick, G. (1978). The external control of organizations: A resource dependency perspective. New York. 
Harper and snow

Preito, P. (n.d). 'Bringing emotion to strategic issue diagnosis: contribution from emotional psychology and social psychology'.

Qlueck, W. (1977). Management, NY, the dryben press.

Rene Olie (2010). ' Top management teams and societal context: the internationaldimensions of top management', in Devinney Timothy, Pedersen Torben, Tihanyi Laszlo (ed.) The Past, Present and Future of International Business \& Management, (Advances in International Management, 23. Emerald Group Publishing Limited, 375 - 398.

Schein, E. (1985) .Organizational culture and leadership, $4^{\text {th }}$ ed; Jossey Bass,USA.

Schneider, 1. (1994) 'Interpreting strategic issues: making sense of '1992' Advances in managerial cognition and organizational information processing.'

Scott, J., \& Ofari- Dankwa, J. (2008). ' Towards an integrative cartography of two strategic issue diagnosis frameworks' Strategic management journal, 29, 93-114.

Simons, R. (2000). Performance measurement and control systems for implementing strategy. Prentice hall, New Jersey.

Smircich, L., \& Morgan, G. (1982). 'Leadership. The management of meaning'. Journal of Applied Behavior Science, 18 .

Sproull, L. (1982). Handbooks of organizational design. Oxford University press, oxford, 203-225.

Staw, B., Sanderland, L., \& Dutton, J. (1981).'Threat rigidity effects in organizational behavior: A multilevel analysis'. Administrative Science Quarterly, 26, 501-524.

Steven, O., \& Karen, S.(2012). 'Characteristics of Non-Budget Firms: Strategy, Environment, Planning, Firm Performance Evaluations and Management Incentive Rewards', in Marc J. Epstein, John Y. Lee (ed.) Advances in Management Accounting , Volume 21, Emerald Group Publishing Limited, 207 - 231.

Stubbart, C. (1987). 'Cognitive science and strategic management: Theoretical and methodological issues. Best paper proceedings'. Academy of Management.

Sutcliffe, K. (1994). 'What executives notice? Accurate perception in top management teams'. Academy of Management Journal, 31.

Taylor, R. (1975). 'Psychological determinants of bounded rationality: implications for decision - making strategies'. Decision Science, 6.

Thomas, L. P., \& William, H. (2004). Critical competitive methods, generic strategies, and firm performance' The international Journal of Bank Marketing, 22(1), 43-64.

Thomas, B., \& McDaniel, R. (1990). 'Interpreting strategic issues: effects of strategy and the information - processing structure of top management teams'. Academy of Management Journal, 33(2), 286-306.

Thomas, B., Gioia, A., \& Ketcher, J. (1997). 'Strategic sense making: learning through scanning, interpretation, action and performance.' Advances in strategic management, 14.

Thomas, J., Clark, S., \& Gioia, D. (1993). 'Strategic sense making and organizational performance: linkages among scanning, interpretation, and action'. Academy of Management Journal.

Tiina Galle'n (2009). 'Top management team composition \& views of viable strategies', Team Performance Management, 15(7/8), 236-342.

Umokoro, G. (2009). 'The effect managerial characteristics and organizational growth on strategic change'. Inter Metro Business Journal, 5(1).

Unterhalter, E. (2012) 'Mutable Meanings: Gender Equality in Education and International Rights Frameworks', The Equal Rights Review, 8.

Weick, K. (1979). Cognitive process in organizations. Research in organizational behavior, Vol. 1, JAI Press, Greenwich, CT, 41-74.

William C. Auden, Joshua D. Shackman \& Marian h. Onken, (2006). 'Top management team, international risk management factors and firm performance' Team Performance management, 12(7/8), 209 -224.

Yesil, S., \& Kaya A. (2013). 'The effects of organizational culture on firm financial performance: Evidence from a developing country', Procedia-Social and Behavioral Sciences, 81(28), 428-437

Yin, R. (1984). Case study research: Design and Methods. Beverly Hills, Calif: Sage publications. 
Zeng, P., \& Wu, Q. H. (2012). 'A review of the Relationship between Female Participation in TMT and Corporate Governance', Economic Management Journal.

Zhao, B.. \& Wu, H. (2013). 'The Analysis of the Effect of Gender Differences of Executives on the Listed Company Investment', Value Engineering.

Zheng, J. (2012). 'CFO Gender and Accrued Earnings Quality: Evidence from China’s Listed Compnies', Journal of Guangxi University of Finance and Economics.

Zheng, W., Yang, B., \& McLean, G.N. (2009). 'Linking organizational culture, strategy, and organizational effectiveness: Mediating the role of knowledge management' Procedia-Social and Behavioral Sciences, 81(28), 428-437 


\section{Appendix}

Appendix 1. Respondents perception on organizational factors that influenced SID process in CUEA

\begin{tabular}{|c|c|c|c|c|c|c|}
\hline Statement & SD & $\mathrm{D}$ & $\mathrm{N}$ & A & SA & $\mathrm{M}$ \\
\hline $\begin{array}{l}\text { 1. The organization has adequate systems to } \\
\text { carry out administrative procedure? }\end{array}$ & $\begin{array}{c}1 \\
(2.9 \%)\end{array}$ & $\begin{array}{c}2 \\
(5.7 \%)\end{array}$ & $\begin{array}{c}5 \\
(14.3 \%)\end{array}$ & $\begin{array}{c}22 \\
(62.9 \%)\end{array}$ & $\begin{array}{c}5 \\
(14.3 \%)\end{array}$ & 3.8000 \\
\hline $\begin{array}{l}\text { 2. The organization is diplomatic in how it } \\
\text { handles aspects of operations? }\end{array}$ & $\begin{array}{c}1 \\
(2.9 \%)\end{array}$ & $\begin{array}{c}3 \\
(8.6 \%)\end{array}$ & $\begin{array}{c}11 \\
(31.4 \%)\end{array}$ & $\begin{array}{c}14 \\
(40 \%)\end{array}$ & $\begin{array}{c}6 \\
(17.1 \%)\end{array}$ & 3.6000 \\
\hline $\begin{array}{l}\text { 3. The organization is authoritative in how it } \\
\text { handles aspects of operations? }\end{array}$ & $\begin{array}{c}2 \\
(5.7 \%)\end{array}$ & $\begin{array}{c}7 \\
(20 \%)\end{array}$ & $\begin{array}{c}13 \\
(37.1 \%)\end{array}$ & $\begin{array}{c}12 \\
(34.3 \%)\end{array}$ & $\begin{array}{c}1 \\
(2.9 \%)\end{array}$ & 3.0857 \\
\hline 4. The organization has clear job descriptions & - & $\begin{array}{c}12 \\
(34.3 \%)\end{array}$ & $\begin{array}{c}9 \\
(25.7 \%)\end{array}$ & $\begin{array}{c}12 \\
(34.3 \%)\end{array}$ & $\begin{array}{c}2 \\
(5.7 \%)\end{array}$ & 3.1143 \\
\hline $\begin{array}{l}\text { 5. The organization has a well- developed } \\
\text { strategy to achieve its purpose? }\end{array}$ & $\begin{array}{c}1 \\
(2.9 \%)\end{array}$ & $\begin{array}{c}6 \\
(17.1 \%)\end{array}$ & $\begin{array}{c}4 \\
(11.4 \%)\end{array}$ & $\begin{array}{c}17 \\
(48.6 \%)\end{array}$ & $\begin{array}{c}7 \\
(20 \%)\end{array}$ & 3.6571 \\
\hline $\begin{array}{l}\text { 6. The organization has a clearly defined } \\
\text { purpose to which all concerned are } \\
\text { committed? }\end{array}$ & $\begin{array}{c}1 \\
(2.9 \%)\end{array}$ & $\begin{array}{c}4 \\
(11.4 \%)\end{array}$ & $\begin{array}{c}8 \\
(22.9 \%)\end{array}$ & $\begin{array}{c}15 \\
(42.9 \%)\end{array}$ & $\begin{array}{c}7 \\
(20 \%)\end{array}$ & 3.6571 \\
\hline $\begin{array}{l}\text { 7. The organizations management team } \\
\text { members identify their own roles with } \\
\text { organizational strategy? }\end{array}$ & $\begin{array}{c}1 \\
(2.9 \%)\end{array}$ & $\begin{array}{c}5 \\
(14.3 \%)\end{array}$ & $\begin{array}{c}10 \\
(28.6 \%)\end{array}$ & $\begin{array}{c}14 \\
(40 \%)\end{array}$ & $\begin{array}{c}5 \\
(14.3 \%)\end{array}$ & 3.4857 \\
\hline $\begin{array}{l}\text { 8. The organization is moving in the right } \\
\text { direction? }\end{array}$ & $\begin{array}{c}1 \\
(2.9 \%)\end{array}$ & $\begin{array}{c}2 \\
(5.7 \%)\end{array}$ & $\begin{array}{c}13 \\
(37.1 \%)\end{array}$ & $\begin{array}{c}12 \\
(34.3 \%)\end{array}$ & $\begin{array}{c}7 \\
(20 \%)\end{array}$ & 3.6286 \\
\hline $\begin{array}{l}\text { 9. The organization shows respect for a diverse } \\
\text { range of opinions, ideas, and people? }\end{array}$ & $\begin{array}{c}2 \\
(5.7 \%)\end{array}$ & $\begin{array}{c}5 \\
(14.3 \%)\end{array}$ & $\begin{array}{c}4 \\
(11.4 \%)\end{array}$ & $\begin{array}{c}18 \\
(51.4 \%)\end{array}$ & $\begin{array}{c}6 \\
(17.1 \%)\end{array}$ & 3.6000 \\
\hline $\begin{array}{l}\text { 10. The organizations management team is } \\
\text { diverse in nature? }\end{array}$ & $\begin{array}{c}2 \\
(5.7 \%)\end{array}$ & $\begin{array}{c}3 \\
(8.6 \%)\end{array}$ & $\begin{array}{c}4 \\
(11.4 \%)\end{array}$ & $\begin{array}{c}16 \\
(45.7 \%)\end{array}$ & $\begin{array}{c}10 \\
(28.6 \%)\end{array}$ & 3.8286 \\
\hline $\begin{array}{l}\text { 11. The organization's management shares same } \\
\text { values concerning the way it operates? }\end{array}$ & $\begin{array}{c}1 \\
(2.9 \%)\end{array}$ & $\begin{array}{c}3 \\
(8.6 \%)\end{array}$ & $\begin{array}{c}11 \\
(13.4 \%)\end{array}$ & $\begin{array}{c}16 \\
(45.7 \%)\end{array}$ & $\begin{array}{c}4 \\
(11.4 \%)\end{array}$ & 3.5429 \\
\hline 12. The organization values my opinion? & $\begin{array}{c}2 \\
(5.7 \%)\end{array}$ & $\begin{array}{c}4 \\
(11.4 \%)\end{array}$ & $\begin{array}{c}13 \\
(37.1 \%)\end{array}$ & $\begin{array}{c}13 \\
(37.1 \%)\end{array}$ & $\begin{array}{c}3 \\
(8.6 \%)\end{array}$ & 3.3143 \\
\hline $\begin{array}{l}\text { 13. The organization celebrates success of team } \\
\text { members? }\end{array}$ & $\begin{array}{c}2 \\
(5.7 \%)\end{array}$ & $\begin{array}{c}6 \\
(17.1 \%)\end{array}$ & $\begin{array}{c}9 \\
(25.7 \%)\end{array}$ & $\begin{array}{c}14 \\
(40 \%)\end{array}$ & $\begin{array}{c}4 \\
(11.4 \%)\end{array}$ & 3.3429 \\
\hline $\begin{array}{l}\text { 14. The organization communicates effectively } \\
\text { (written or verbal)? }\end{array}$ & $\begin{array}{c}1 \\
(2.9 \%)\end{array}$ & $\begin{array}{c}9 \\
(25.7 \%)\end{array}$ & $\begin{array}{c}12 \\
(34.3 \%)\end{array}$ & $\begin{array}{c}12 \\
(34.3 \%)\end{array}$ & $\begin{array}{c}1 \\
(2.9 \%)\end{array}$ & 3.0857 \\
\hline $\begin{array}{l}\text { 15. The organization communicates all } \\
\text { information in a timely fashion? }\end{array}$ & $\begin{array}{c}2 \\
(5.7 \%)\end{array}$ & $\begin{array}{c}13 \\
(37.1 \%)\end{array}$ & $\begin{array}{c}10 \\
(28.6 \%)\end{array}$ & $\begin{array}{c}10 \\
(28.6 \%)\end{array}$ & - & 2.8000 \\
\hline $\begin{array}{l}\text { 16. The organization has an effective system for } \\
\text { circulating information to all concerned? }\end{array}$ & & $\begin{array}{c}8 \\
(22.9 \%)\end{array}$ & $\begin{array}{c}12 \\
(34.3 \%)\end{array}$ & $\begin{array}{c}13 \\
(37.1 \%)\end{array}$ & $\begin{array}{c}2 \\
(5.7 \%)\end{array}$ & 3.2571 \\
\hline $\begin{array}{l}\text { 17. The organizations management group work } \\
\text { as a team, not individually? }\end{array}$ & & $\begin{array}{c}6 \\
(17.1 \%)\end{array}$ & $\begin{array}{c}7 \\
(20 \%)\end{array}$ & $\begin{array}{c}20 \\
(57.1 \%)\end{array}$ & $\begin{array}{c}2 \\
(5.7 \%)\end{array}$ & 3.5143 \\
\hline $\begin{array}{l}\text { 18. The organization has a spirit of open } \\
\text { communication? }\end{array}$ & - & $\begin{array}{c}8 \\
(22.9 \%)\end{array}$ & $\begin{array}{c}9 \\
(25.7 \%)\end{array}$ & $\begin{array}{c}13 \\
(37.1 \%)\end{array}$ & $\begin{array}{c}4 \\
(11.4 \%)\end{array}$ & 3.3143 \\
\hline $\begin{array}{l}\text { 19. The organizations management team's } \\
\text { personality profile affects decision speed? }\end{array}$ & - & $\begin{array}{c}5 \\
(14.3 \%)\end{array}$ & $\begin{array}{c}10 \\
(28.6 \%)\end{array}$ & $\begin{array}{c}20 \\
(57.1 \%)\end{array}$ & & 3.4286 \\
\hline $\begin{array}{l}\text { 20. The organizations management team } \\
\text { members show high action orientation? }\end{array}$ & - & $\begin{array}{c}8 \\
(22.9 \%)\end{array}$ & $\begin{array}{c}15 \\
(42.9 \%)\end{array}$ & $\begin{array}{c}11 \\
(13.4 \%)\end{array}$ & $\begin{array}{c}1 \\
(2.9 \%)\end{array}$ & 3.1429 \\
\hline $\begin{array}{l}\text { 21. The organizations management team shows } \\
\text { high flexibility? }\end{array}$ & $\begin{array}{c}2 \\
(5.7 \%)\end{array}$ & $\begin{array}{c}8 \\
(22.9 \%)\end{array}$ & $\begin{array}{c}11 \\
(31.4 \%)\end{array}$ & $\begin{array}{c}13 \\
(37.1 \%)\end{array}$ & $\begin{array}{c}1 \\
(2.9 \%)\end{array}$ & 3.0857 \\
\hline $\begin{array}{l}\text { 22. The organizations management team shows } \\
\text { high achievement orientation? }\end{array}$ & $\begin{array}{c}1 \\
(92.9 \%)\end{array}$ & $\begin{array}{c}4 \\
(11.4 \%)\end{array}$ & $\begin{array}{c}13 \\
(37.1 \%)\end{array}$ & $\begin{array}{c}16 \\
(45.7 \%)\end{array}$ & $\begin{array}{c}1 \\
(2.9 \%)\end{array}$ & 3.3429 \\
\hline $\begin{array}{l}\text { 23. The organization's management team } \\
\text { member's background diversity affects } \\
\text { timing of agenda - setting? }\end{array}$ & $\begin{array}{c}1 \\
(2.9 \%)\end{array}$ & $\begin{array}{c}4 \\
(11.4 \%)\end{array}$ & $\begin{array}{c}13 \\
(37.1 \%)\end{array}$ & $\begin{array}{c}16 \\
(45.7 \%)\end{array}$ & $\begin{array}{c}1 \\
(2.9 \%)\end{array}$ & 3.3429 \\
\hline $\begin{array}{l}\text { 24. The organization's top management team } \\
\text { members' background diversity affects the } \\
\text { generation of strategic decisions? }\end{array}$ & $\begin{array}{c}3 \\
(8.6 \%)\end{array}$ & $\begin{array}{c}2 \\
(5.7 \%)\end{array}$ & $\begin{array}{c}13 \\
(37.1 \%)\end{array}$ & $\begin{array}{c}16 \\
(45.7 \%)\end{array}$ & $\begin{array}{c}1 \\
(2.9 \%)\end{array}$ & 3.2857 \\
\hline
\end{tabular}


25. The organization has a system for identifying problems?

26. The organization has a system for analyzing opinions, thus taking relevant decisions?

27. The organizations information, communication and technological (ICT) infrastructure is sufficient?

28. The organizations ICT system assists in management of information i.e. collection of data, manipulation, processing and keeping it secure?

29. The organizations ICT infrastructure assists in achievement of organizational goals and objectives?

Average

$\begin{array}{cccccc}5 & 7 & 10 & 12 & 1 & 2.9143 \\ (14.3 \%) & (20 \%) & (28.6 \%) & (34.3 \%) & (2.9 \%) & \\ 3 & 10 & 6 & 15 & 1 & 3.0286 \\ (8.6 \%) & (28.6 \%) & (17.1 \%) & (42.9 \%) & (2.9 \%) & \end{array}$

$\begin{array}{llll}15 & 1 & 6 & 1\end{array}$

$(42.9 \%) \quad(37.1 \%) \quad(17.1 \%) \quad(2.9 \%)$

2.9714

$\begin{array}{llll}2 & 13 & 11 & 9\end{array}$

$(5.7 \%) \quad(37.1 \%) \quad(31.4 \%) \quad(25.7 \%)$

$\begin{array}{llllll}2 & 13 & 12 & 6 & 2 & 2.8000\end{array}$

$\begin{array}{llll}(5.7 \%) & (37.1 \%) & (34.3 \%) & (17.1 \%)\end{array}$
2.7714

(1)

Source: survey results, $2011 \quad \mathrm{n}=35$

Appendix 2. Total variance explained by factor scores of internal organizational contextual factors that affect SID in CUEA

\begin{tabular}{|c|c|c|c|c|c|c|c|c|c|}
\hline \multirow[b]{2}{*}{ Component } & \multicolumn{3}{|c|}{ Initial Eigen values } & \multicolumn{3}{|c|}{$\begin{array}{l}\text { Extraction } \\
\text { Loadings }\end{array}$} & \multicolumn{3}{|c|}{ Rotation Sums of Squared Loadings } \\
\hline & Total & $\begin{array}{l}\% \text { of } \\
\text { Variance }\end{array}$ & Cumulative \% & Total & Variance & Cumulative \% & Total & $\begin{array}{l}\% \text { of } \\
\text { Variance }\end{array}$ & Cumulative \% \\
\hline 1 & 12.609 & 43.479 & 43.479 & 12.609 & 43.479 & 43.479 & 6.460 & 22.276 & 22.276 \\
\hline 2 & 3.028 & 10.441 & 53.920 & 3.028 & 10.441 & 53.920 & 4.333 & 14.940 & 37.216 \\
\hline 3 & 2.018 & 6.960 & 60.879 & 2.018 & 6.960 & 60.879 & 3.080 & 10.621 & 47.838 \\
\hline 4 & 1.768 & 6.096 & 66.975 & 1.768 & 6.096 & 66.975 & 2.857 & 9.850 & 57.688 \\
\hline 5 & 1.227 & 4.231 & 71.206 & 1.227 & 4.231 & 71.206 & 2.619 & 9.033 & 66.720 \\
\hline 6 & 1.078 & 3.717 & 74.923 & 1.078 & 3.717 & 74.923 & 2.379 & 8.202 & 74.923 \\
\hline 7 & .973 & 3.354 & 78.276 & & & & & & \\
\hline 8 & .907 & 3.128 & 81.404 & & & & & & \\
\hline 9 & .746 & 2.574 & 83.978 & & & & & & \\
\hline 10 & .673 & 2.321 & 86.299 & & & & & & \\
\hline 11 & .602 & 2.076 & 88.375 & & & & & & \\
\hline 12 & .512 & 1.766 & 90.141 & & & & & & \\
\hline 13 & .474 & 1.634 & 91.775 & & & & & & \\
\hline 14 & .396 & 1.365 & 93.140 & & & & & & \\
\hline 15 & .362 & 1.248 & 94.388 & & & & & & \\
\hline 16 & .271 & .934 & 95.322 & & & & & & \\
\hline 17 & .267 & .920 & 96.242 & & & & & & \\
\hline 18 & .224 & .772 & 97.014 & & & & & & \\
\hline 19 & .203 & .701 & 97.715 & & & & & & \\
\hline 20 & .164 & .567 & 98.282 & & & & & & \\
\hline 21 & .141 & .485 & 98.767 & & & & & & \\
\hline 22 & .102 & .351 & 99.119 & & & & & & \\
\hline 23 & .087 & .299 & 99.418 & & & & & & \\
\hline 24 & .058 & .199 & 99.617 & & & & & & \\
\hline 25 & .046 & .158 & 99.775 & & & & & & \\
\hline 26 & .032 & .112 & 99.887 & & & & & & \\
\hline 27 & .022 & .077 & 99.964 & & & & & & \\
\hline 28 & .007 & .024 & 99.988 & & & & & & \\
\hline 29 & .003 & .012 & 100.000 & & & & & & \\
\hline
\end{tabular}


Extraction Method: Principal Component Analysis.

Appendix 3. Rotated Component Matrix (a)

\begin{tabular}{|c|c|c|c|c|c|c|c|}
\hline Question & 1 & 2 & 3 & 4 & 5 & 6 & Interpretation \\
\hline Q13 Celebrates success of team members. & .809 & & & & & & \\
\hline Q7 Management team work as a group & 696 & & & & & & \\
\hline Q12 Organization values opinions & 689 & & & & & & \\
\hline $\begin{array}{l}\text { Q18 Organization has a spirit of open } \\
\text { communication }\end{array}$ & .676 & & & & & & \\
\hline Q21 Management team show high flexibility & 675 & & & & & & \\
\hline $\begin{array}{l}\text { Q25 Organization has a system for identifying } \\
\text { problems }\end{array}$ & 668 & & & & & & \\
\hline $\begin{array}{l}\text { Q26 System for analyzing opinions, thus taking } \\
\text { relevant decisions. }\end{array}$ & 661 & & & & & & $\begin{array}{l}\text { Organizational } \\
\text { culture }\end{array}$ \\
\hline $\begin{array}{l}\text { Q22 Management team show high action } \\
\text { orientation. }\end{array}$ & 627 & & & & & & \\
\hline $\begin{array}{l}\text { Q9 Respect for diverse range of opinions, ideas } \\
\text { and people. }\end{array}$ & 602 & & & & & & \\
\hline Q6 Clearly defined purpose. & .591 & & & & & & \\
\hline Q2 Diplomatic in its operations. & .548 & & & & & & \\
\hline Q3 Authoritative in its operations. & -.519 & & & & & & \\
\hline Q14 Organization communicates effectively & & .907 & & & & & \\
\hline $\begin{array}{l}\text { Q15 Organization communicates all information } \\
\text { in a timely fashion. }\end{array}$ & & .817 & & & & & \\
\hline $\begin{array}{l}\text { Q16 Effective system for dissemination of } \\
\text { information. }\end{array}$ & & .686 & & & & & $\begin{array}{l}\text { Communication } \\
\text { system }\end{array}$ \\
\hline Q4 Clear job descriptions. & & .655 & & & & & \\
\hline Q11 Management team shares same values & & 619 & & & & & \\
\hline $\begin{array}{l}\text { Q24 Background diversity affects generation of } \\
\text { strategic decisions. }\end{array}$ & & & .761 & & & & Personality profile \\
\hline Q19 Personality profile affects decision speed. & & & .704 & & & & of managers \\
\hline $\begin{array}{l}\text { Q23 Background diversity affects timing of } \\
\text { agenda setting. }\end{array}$ & & & .609 & & & & \\
\hline Q10 Management team is diverse in nature. & & & .603 & & & & \\
\hline Q1 Adequate administrative procedures. & & & & .782 & & & $\begin{array}{l}\text { Organizational } \\
\text { structure }\end{array}$ \\
\hline Q5 Well developed strategy & & & & .633 & & & \\
\hline Q8 Moving in the right direction & & & & & .744 & & \\
\hline Q7Identify own role with right strategy. & & & & & .607 & & Organizational \\
\hline Q27ICT system is sufficient & & & & & .531 & & strategy \\
\hline Q28ICT system assists in management of & & & & & & .804 & ICT svstems \\
\hline $\begin{array}{l}\text { Q29ICT infrastructure in achievement of } \\
\text { organizational goals and objectives. }\end{array}$ & & & & & & .734 & \\
\hline
\end{tabular}

Extraction Method: Principal Component Analysis. Rotation Method: Varimax with Kaiser Normalization. A Rotation converged in 15 iterations.

Appendix 4. Total variance explained by factor score of the impact of Factors affecting SID on performance of CUEA



Extraction Method: Principal Component Analysis. 
Appendix 5. Rotated Component Matrix (a)

\begin{tabular}{|c|c|c|c|c|}
\hline Factor & 1 & 2 & 3 & Interpretation \\
\hline Q37 Achievement of organizational goals and objectives. & .845 & & & \multirow{5}{*}{ Profitability } \\
\hline Q38 Organizations ability to things in the right way & .761 & & & \\
\hline Q34 Level of student enrollment in CUEA & .696 & & & \\
\hline Q35 Rate of return on investment & .696 & & & \\
\hline Q39 The ability of the organization to do the right thing & .652 & & & \\
\hline Q32 Rate of staff turnover. & & .893 & & \multirow{4}{*}{$\begin{array}{l}\text { Customer } \\
\text { satisfaction }\end{array}$} \\
\hline Q33 Staff morale & & .796 & & \\
\hline Q30 Number of student complaints. & & .774 & & \\
\hline Q31 Rate of student transfers & & .736 & & \\
\hline Q36Number of student graduants from CUEA. & & & .905 & No. of graduants \\
\hline
\end{tabular}

Extraction Method: Principal Component Analysis. Rotation Method: Varimax with Kaiser Normalization. A Rotation converged in 5 iterations.

Appendix 6. Respondents perceptions on what can be done to improve SID

\begin{tabular}{|c|c|c|c|c|c|c|c|}
\hline \multicolumn{2}{|c|}{ Statement } & \multirow{2}{*}{$\begin{array}{l}\mathrm{SD} \\
-\end{array}$} & \multirow{2}{*}{$\begin{array}{l}\mathrm{D} \\
-\end{array}$} & \multirow{2}{*}{$\begin{array}{l}\mathrm{N} \\
2(5.7 \%)\end{array}$} & \multirow{2}{*}{$\begin{array}{l}\text { A } \\
10(28.6 \%)\end{array}$} & \multirow{2}{*}{$\begin{array}{l}\text { SA } \\
23(65.7 \%)\end{array}$} & \multirow{2}{*}{$\begin{array}{l}\text { Mean } \\
4.6000\end{array}$} \\
\hline 1. & $\begin{array}{l}\text { Management team SHOULD correctly analyze the } \\
\text { existing culture by evaluating it against the cultural } \\
\text { attributes needed to achieve strategic objectives? }\end{array}$ & & & & & & \\
\hline 2. & $\begin{array}{l}\text { Management team SHOULD ensure organizational } \\
\text { structure fits company's goals and objectives? }\end{array}$ & - & $1(2.9 \%)$ & $1(2.9 \%)$ & $8(22.9 \%)$ & $25(71.4 \%)$ & 4.6286 \\
\hline 3. & $\begin{array}{l}\text { Management SHOULD develop organizational } \\
\text { strategy/ initiatives that convert strategic intent into } \\
\text { suitable results? }\end{array}$ & - & - & $2(5.7 \%)$ & $9(25.7 \%)$ & $24(68.6 \%)$ & 4.6286 \\
\hline 4. & $\begin{array}{l}\text { Management SHOULD ensure good planning, } \\
\text { administration and control of ICT infrastructure? }\end{array}$ & - & - & $2(5.7 \%)$ & $7(20 \%)$ & $26(74.3 \%)$ & 4.6857 \\
\hline 5. & $\begin{array}{l}\text { Management team SHOULD ensure that suitable } \\
\text { resources with right skills and competencies are } \\
\text { produced and retained to undertake necessary roles in } \\
\text { the organization? }\end{array}$ & - & $1(2.9 \%)$ & - & $9(25.7 \%)$ & $25(71.4 \%)$ & 4.6571 \\
\hline \multicolumn{2}{|c|}{ Average } & & & & & & 4.6 \\
\hline
\end{tabular}

Appendix 7. Biographies of Authors

1. Aloys Ayako is an Associate Professor of Economics at the Catholic University of Eastern Africa (CUEA). He holds a PhD and Masters of Political Economy (MAPE) degrees from Boston University in the USA and Masters of Economics degree from the University of Nairobi (UON) in Kenya. He has over thirty years of teaching, supervision of PhD and Masters Degrees' theses and research projects and research experience. He has published widely in peer reviewed journals.

2. Annette Ayako is a Compliance Officer at the National Social Security Fund (NSSF). She has recently completed her Masters of Business Administration (MBA) from Faculty of Commerce of CUEA and is currently enrolled for PhD studies at the Jomo Kenyatta University of Agriculture and Technology (KUAT).

\section{(cc) $E_{Y}$}

This work is licensed under a Creative Commons Attribution 3.0 License. 